Research Article

\title{
Electromagnetic Radiation Measurements and Safety Issues of some Cellular Base Stations in Nablus
}

\author{
A. Mousa* \\ Electrical Engineering Department, An Najah University, Palestine.
}

Received 17 July 2010; Accepted 20 February 2011

\begin{abstract}
As the mobile telecommunication systems are tremendously growing allover the world then the numbers of handheld and base stations are also rapidly growing and it became very popular to see these base stations distributed everywhere in the neighborhood and on roof tops which has caused a considerable amount of panic to the public in Palestine concerning wither the radiated electromagnetic field from these base stations may cause any health effect or hazard. This paper focuses on the radiated electromagnetic energy from some typical mobile base stations around the city of Nablus. The exposure levels due to these stations were measured and compared to some international standard guidelines like ICNIRP and FCC to see if it meets these standards, this is in order to answer some of the public fear and concern. The results are presented and some comments are made on the other sources of electromagnetic radiation in the $200 \mathrm{kHz}$ to $3 \mathrm{GHz}$ range.
\end{abstract}

Keywords: Electromagnetic pollution, mobile base station, exposure limitations.

\section{Introduction}

Electromagnetic Field (EMF) and waves are an important and main media to carry signals from a certain source to the desired destination; this signal can be voice, data or image. The EMF is propagating at the speed of light in free space $(300,000 \mathrm{~km} / \mathrm{s})$ so it can be modulated, transmitted and received while conveying the necessary information [1], [2] and [3].

This electromagnetic wave consists of an electric field perpendicular to the magnetic field and both are perpendicular to the direction of propagation as shown in Figure 1. The wave length of the wave depends on the operating frequency.

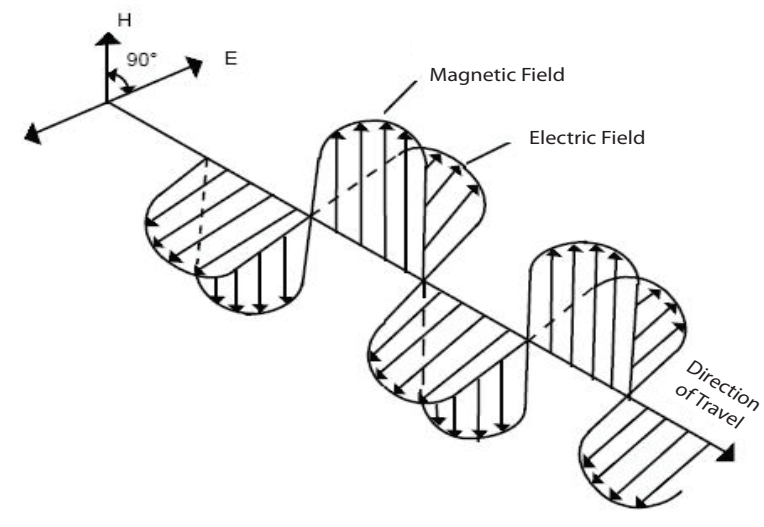

Figure 1. The electromagnetic wave
Different types of electromagnetic waves have different frequencies as shown by the electromagnetic spectrum in Figure 2. Each of these frequencies has its own properties and characteristics which make it distinguished from others. The Electromagnetic radiation may be classified as ionizing and non-ionizing radiation. Ionizing radiation has enough energy to remove bound electrons from the orbit of an atom such that it becomes an ionized atom which may cause health hazard. On the other hand, the non-ionizing radiation does not have the sufficient energy to ionize (change) the atoms. For example, the human eye can easily perceive the light whereas the EMF with very high frequency, like X-ray, may ionize material and break down molecules. However, this radioactive radiation should not be confused with radio wave frequency (RF).

The radio waves used in mobile telephones and cellular communications are also electromagnetic waves like visible light and $\mathrm{X}$-ray and they also propagate in the same speed of light. The $\mathrm{RF}$ used for mobile communication can be in the range 450-2200 $\mathrm{MHz}$ which is considered as part of the microwave (MW) range as shown in Figure 2. It is also shows the range of non-ionizing and ionizing ranges of frequency and the applications of each one as well as the energy associated with each one. Obviously, the wave energy is directly proportional to the wave frequency. 


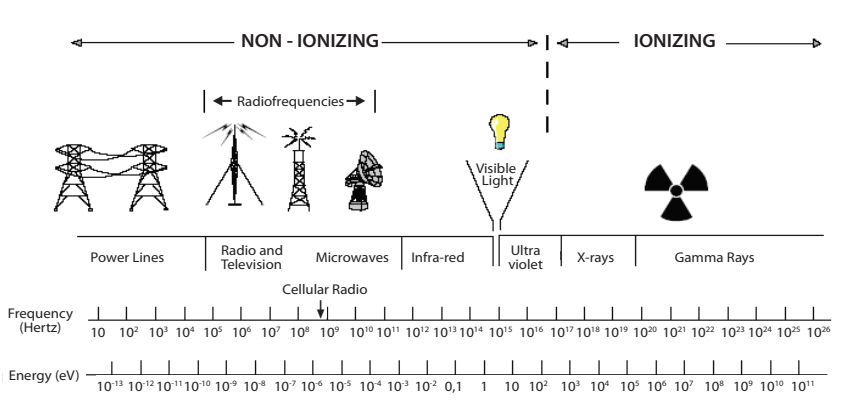

Figure 2. The electromagnetic spectrum, energy and some applications

\section{Cellular Networks}

A cellular communication system is one of the most increasing telecommunication sectors. It consists of several transmitters, called base stations, covering adjoining zones, called cells, and the used mobile phones. There exist several mobile radio systems in the world ranging from analog to digital systems and having different multiple access types and frequency carriers. The main three systems are the North America, European and Japan systems where each of these systems was developed and through generations. The specifications of these systems are illustrated in Table 1, Table 2 and Table 3 respectively.

Table 1. Mobile radio systems in USA.

\begin{tabular}{|c|c|c|c|c|c|}
\hline Cellular system & Year & $\begin{array}{l}\text { Transmis- } \\
\text { sion type }\end{array}$ & $\begin{array}{c}\text { Multiple } \\
\text { access } \\
\text { type }\end{array}$ & $\begin{array}{c}\text { Channel } \\
\text { Bandwidth }\end{array}$ & $\begin{array}{c}\text { Genera- } \\
\text { tion }\end{array}$ \\
\hline $\begin{array}{l}\text { Advanced Mobile } \\
\text { Phone system } \\
\text { AMPS }\end{array}$ & 1983 & Analog & FDMA & $800 \mathrm{MHz}$ & $1^{\text {st }}$ \\
\hline $\begin{array}{l}\text { Narrowband } \\
\text { AMPS }\end{array}$ & 1992 & Analog & FDMA & $800 \mathrm{MHz}$ & $1^{\text {st }}$ \\
\hline $\begin{array}{l}\text { US Digital Cellular } \\
\text { Digital AMPS } \\
\text { IS-45/IS-136 }\end{array}$ & 1991 & Digital & TDMA & $\begin{array}{c}800 / \\
1900 \mathrm{MHz}\end{array}$ & $2^{\text {nd }}$ \\
\hline $\begin{array}{l}\text { US Narrowband } \\
\text { Spread Spectrum } \\
\text { IS-95,CDMAone }\end{array}$ & 1993 & Digital & CDMA & $\begin{array}{c}800 / \\
1900 \mathrm{MHz}\end{array}$ & $2^{\text {nd }}$ \\
\hline CDMA-2000 & 2001 & Digital & CDMA & $1900 \mathrm{MHz}$ & $3^{\text {rd }}$ \\
\hline
\end{tabular}

Table 2. Mobile radio systems around the world.

\begin{tabular}{lccccc}
\hline Cellular system & Year & $\begin{array}{c}\text { Trans-mis- } \\
\text { sion type }\end{array}$ & $\begin{array}{c}\text { Multiple } \\
\text { access } \\
\text { type }\end{array}$ & $\begin{array}{c}\text { Channel } \\
\text { Bandwidth }\end{array}$ & $\begin{array}{c}\text { Genera- } \\
\text { tion }\end{array}$ \\
\hline $\begin{array}{l}\text { Total Access } \\
\text { Communication } \\
\text { ETACS }\end{array}$ & 1985 & Analog & FDMA & $900 \mathrm{MHz}$ & $1^{\text {st }}$ \\
$\begin{array}{l}\text { Nordic Mobile } \\
\text { Telephone }\end{array}$ & 1986 & Analog & FDMA & $450 / 900 \mathrm{MHz}$ & $1^{\text {st }}$ \\
$\begin{array}{l}\text { NMT-900 } \\
\begin{array}{l}\text { Global system of } \\
\text { Mobile GSM }\end{array}\end{array}$ & 1990 & Digital & TDMA & $900 / 1800$ & $2^{\text {nd }}$ \\
$\begin{array}{l}\text { UNIVERSAL } \\
\text { Mobile Telecom }\end{array}$ & 2001 & Digital & CDMA & $2000 \mathrm{MHz}$ & $2^{\text {nd }}$ \\
$\begin{array}{l}\text { System } \\
\text { UMTS WCDMA }\end{array}$ & & & & & \\
\hline
\end{tabular}

Table 3. Mobile radio systems in Japan.

\begin{tabular}{lccccc}
\hline Cellular system & Year & $\begin{array}{c}\text { Trans- } \\
\text { mission } \\
\text { type }\end{array}$ & $\begin{array}{c}\text { Multiple } \\
\text { access } \\
\text { type }\end{array}$ & $\begin{array}{c}\text { Channel } \\
\text { Band- } \\
\text { width }\end{array}$ & $\begin{array}{c}\text { Gener- } \\
\text { ation }\end{array}$ \\
\hline J-TACS & 1985 & Analog & FDMA & $900 \mathrm{MHz}$ & $1^{\text {st }}$ \\
PDC & 1986 & Digital & TDMA & $900 \mathrm{MHz}$ & $2^{\text {nd }}$ \\
CDMA one (KDDI) & 2000 & Digital & CDMA & $900 \mathrm{MHz}$ & $2^{\text {nd }}$ \\
UMTS WCDMA (NTT Docomo) & 2001 & Digital & CDMA & $2000 \mathrm{MHz}$ & $3^{\text {rd }}$ \\
\hline
\end{tabular}

Considering the GSM system as one of the most popular cellular system allover the world and being the one which is adopted and operating in Palestine, then the operating frequency may be summarized as shown in Table 4.

Table 4. GSM frequency Spectrum.

\begin{tabular}{ccc}
\hline GSM range (MHz) & Uplink (MHz) & Downlink (MHz) \\
\hline 900 & $890-915$ & $935-960$ \\
1800 & $1710-1785$ & $1805-1880$ \\
1900 & $1850-1910$ & $1930-1990$ \\
\hline
\end{tabular}

\section{I) Base Station}

The cells radii many vary in size according to the desired capacity and geographical area to be covered, this ranges from tens of meters in buildings, and hundreds of meters in cities up to tens of kilometers in the countryside [4]. Each of these cells is covered by the allocated base station which is responsible for transmitting and receiving the radio signal required to establish the communication between users. The base station must be designed in a way such that each cell in the network can perform efficiently to achieve good signal, minimum congestion or call drop and no interference [5]. The RF power should be assigned to achieve these goals. It should be large enough to provide coverage and quality but small enough to prevent interference.

To complete a call from any mobile phone, the network assigns a certain available RF channel within the cell that covers the named mobile phone, if this cell is congested then this mobile phone is connected through a neighboring cell, the call is then routed to a switch that will proceed conventionally to the final destination being mobile or fixed destination. In case the user is moving and will cross the boundary of a cell into the range of a neighboring one, the network will "handover" the call from the serving base station into an other one that can provide coverage

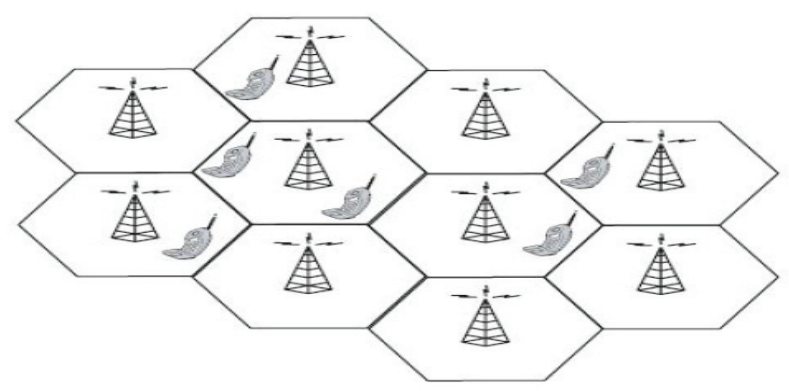

Figure 3. Neighboring cells 
and capacity to this on-going call. An illustration of the neighboring cells is shown in Figure 3. The shape of cells are not perfect circles or hexagonal, but it depends on the environment such as buildings and mountains, it also depends on weather conditions and even system load [4], [5].

It is important to mention here that multiple cells are needed to cover an area both in capacity and signal strength, this is due to the fact that each cell can provide a limited number of instantaneous calls [5]. Hence, as the number of base stations operating at particular carrier frequency increases in a certain area the cell size gets smaller and so less power is required, for transmission, to cover this small-sized cell.

To achieve the desired goals of the base station, antennas with certain power, orientation and gain should be chosen and fixed properly. The gain of the antenna is important but also it should be mounted clearly with no obstacles that may reduce the coverage or signal strength of the base station since these obstacles will force the base station to use higher power to cover the cell which is waste of resources and may cause interference with the neighboring cells. The coverage area of a typical antenna is illustrated in Figure 4 [6].

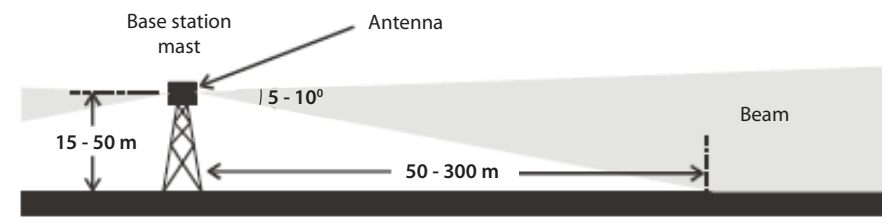

Figure 4. Direction of coverage due to a base station antenna

In small cells case, where mobile phones are highly used, antennas may be installed on building roofs and sides or on small poles (low impact facilities), while in the case of large cells (low usage area), the antennas are usually mounted on masts and towers to deal with the large distances and gains. In both cases, it is desired to maintain service quality to all users. Typical antenna types and way of fixing is illustrated in Figure 5.
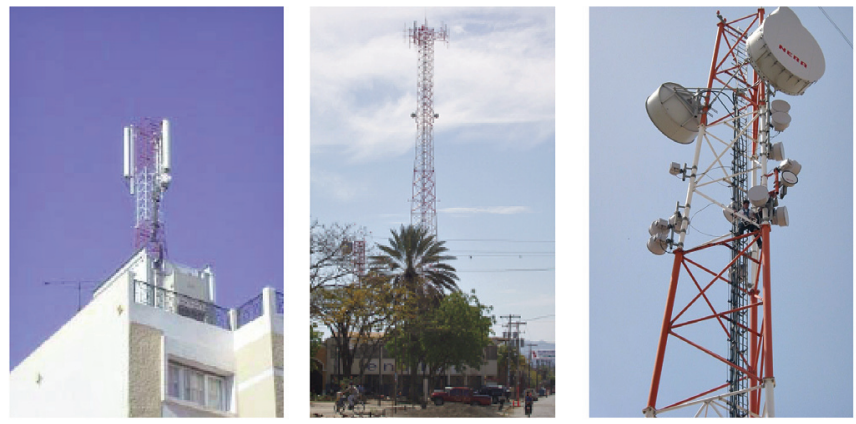

Figure 5. Several antenna types mounted

Typical heights of these antennas are 15-50 meter from ground. A base station may consist of several "omni directional" antennas, each one is directed to a certain geographical direction, and the signal from this antenna is directed to cover the desired area in a relatively narrow beam in the vertical plane as shown in Figure 4. The advantages and disadvantages of cellular systems with small cells are shown in Table 5 .
Table 5. Advantages and disadvantages of small cells cellular communication system.

\begin{tabular}{lc}
\hline \multicolumn{1}{c}{ Advantages } & Disadvantages \\
\hline High capacity & Infrastructure needed \\
Less transmission power & Hardware needed \\
Local interference & Frequency planning \\
$\begin{array}{l}\text { Robustness to failure at single } \\
\text { component }\end{array}$ & \\
\hline
\end{tabular}

\section{II) Mobile phones}

Mobile phones are connected to the base stations via radiofrequency electromagnetic waves (RF-EMF). These mobile phones should be in the coverage area of a certain cell; the base station of this cell must assign this mobile phone the necessary RF channel to maintain the connection. To achieve this link, the mobile should use certain transmission power to connect to the base station (uplink) and the base station should use the required power to connect to the mobile phone (down link).

Similar to the base station case, the mobile phone should not have obstacles since this reduces the signal strength and so the quality becomes poor. Increasing the transmission power means the mobile will not work on the minimum power which results in waste of resources and lose of battery life as well as other problems that may arise.

It is important to conserve the battery life and to minimize the interference between cells and hence the mobile transmission power is limited to the minimum level required to maintain the connection and so it is better to be close to the base station so as to reduces the transmission power in both directions.

\section{III) Quality in Mobile Communications}

The sound quality in mobile communications depends on two items [4], [5], [6]) Strength of the radio signal to convey the data, and 2) No other strong RF signals should present at the same or even adjacent frequencies. To achieve these two points, the mobile and base station must use the appropriate output power. The intensity of the EMF is decreased as the distance from the antenna is increased, this enables use of the same frequency in a new cell at a certain distance from the first base station without any disturbance between these two cells, this is called "frequency-reuse" which is so important to be optimized since the mobile network is limited in frequency spectrum [6].

Actually, the power density (intensity) decreases by a factor of the square of the distance as one move away from the base station. Moreover, the intensity is proportional to the transmitter's output power. Typically the available mobiles have a maximum output power of one watt, but only a fraction of this power is used to establish good communication under the normal conditions. Some typical values of the handset output power, for the most common mobile phone systems, is given in Table 6 .

The output power of a base station ranges from few watts for 
small cells to hundreds of watts for huge cells depending on some parameters such as the type and location. Moreover, this power is usually directed so that the signal is stronger in some directions and weak in the others as it is desired.

Table 6. Typical output power of certain mobile phones handsets.

\begin{tabular}{|c|c|c|c|c|}
\hline $\begin{array}{l}\text { Mobile } \\
\text { telephone } \\
\text { system }\end{array}$ & $\begin{array}{c}\text { Where primar- } \\
\text { ily used }\end{array}$ & Type & $\begin{array}{c}\text { Frequency } \\
\text { band (MHz) }\end{array}$ & $\begin{array}{c}\text { Handset output } \\
\text { power (W) } \\
\text { (maximum) }\end{array}$ \\
\hline NMT & Scandinavia & Analog & 900 & \\
\hline ETACS & UK, Asia & Analog & 900 & 0.6 \\
\hline AMPS & $\begin{array}{l}\text { America, Asia, } \\
\text { Australia }\end{array}$ & Analog & 800 & 0.6 \\
\hline D-AMPS & America, Asia & Digital & $800 / 1900$ & 0.2 \\
\hline GSM & $\begin{array}{c}\text { Europe, Asia, } \\
\text { Australia }\end{array}$ & Digital & 900 & 0.25 \\
\hline PDC & Japan & Digital & $800 / 1500$ & 0.2 \\
\hline GSM1800 & Europe, Asia & Digital & 1800 & 0.125 \\
\hline GSM1900 & North America & Digital & 1900 & 0.125 \\
\hline DECT & Europe, Asia & Digital & 1900 & 0.01 \\
\hline
\end{tabular}

\section{Safety Guidelines to Level of Exposure}

Since it was first introduced around 1980, almost all classes of society are using mobile phones. The estimated number of mobile phone users is around 1.5 billion all over the world [7]. The Cellular Telecommunication Industry Association (CTIA) has reported that this industry is growing at a rate of $40 \%$ per year [8]. This so fast rapid deployment of mobile telecommunications networks in the world has alert public concern over possible health effects from exposure to radiofrequency electromagnetic energy (RF EME) emitted by both mobile phones and base station antennas.

\section{I) Health and Safety}

The exposure to very high levels of RF energy can be harmful and may cause some biological effects on human [9], [10], these effects may result from heating of tissues and it is called "thermal effects" this is mainly due to the ability of RF energy to heat biological tissue, this is the same as the principle of the microwave oven. On the other hand, at low levels of exposure to RF radiation (lower than the threshold which may cause heat), the evidence of harmful biological effects is unproven; however it may cause some non thermal effects [11]. At the extremely high frequencies like X-rays, electromagnetic particles have sufficient energy to break bonds (ionization). This is why genetic material of cells may be damaged leading to cancer or birth defects. However, at lower frequencies, such as the RF ones used by cellular communications, the energy of the particles is too much low to break chemical bonds. Thus, RF energy is non-ionizing [12]

\section{II) Standards and Limitations}

The main concern of RF exposure has started some sixty years ago where several national and international standards, regulations and recommendations for RF energy exposure were developed for both the general public (unconditional exposure) and those who are working with this field (occupational exposure). These exposure guidelines are usually similar and are based on the thresholds for known adverse effects and they have a margin of safety in order to protect people from the health effects of both short and long term exposure to EMF [13]. Some of these standards were organized and developed by the following organizations;

1) World Health Organization (WHO) [13]

2) International Commission on Non-Ionizing Radiation Protection [14]

3) Federal Communications Commission (FCC).

4) Institute of Electrical and Electronic Engineering (IEEE).

5) Environmental Protection Agency (EPA).

6) Food and Drug Administration (FDA).

7) American Cancer Society (ACS)

8) National Institute for Occupational Safety and Health (NI$\mathrm{OSH}$ ).

9) Occupational safety and Health Administration (OSHA)

10) National Council of Radiation Protection and Measurements (NCRPM).

11) Australian Radiation Protection and Nuclear Safety Agency (ARPNSA).

The importance of WHO is that it has established the "International EMF Project" to review the scientific literature concerning the biological effects of electromagnetic fields. The main aim of this project is to provide a frame work for the international harmonization of RF safety standards [13]. The ICNIRP is considered as the most important organization specifying radio frequency EMF limits due to the following items [14];

a) ICNIRP guidelines were published in 1998 .

b) Limits are based on all available scientific research and include large safety margins.

c) Limits are set to protect all people from established adverse health effect from short and long term exposure.

d) Specifies limits for both general public and occupational exposure.

e) Endorsed by WHO.

When the distance to the radio transmitter is in the far field (greater then few wavelengths, i.e., around one meter for RF), safety limits are usually expressed as field strength. The field intensity is usually applied to exposure from base stations. Since RF waves have both electric and magnetic components, the electric field strength is measured in volts per meter $(\mathrm{v} / \mathrm{m})$ and the magnetic field is measured in amperes per meter $(\mathrm{A} / \mathrm{m})$. A commonly used unit to characterize the RF electromagnetic field is the plane wave power density especially at the far field. This density is defined as the power per unit area; it may be expressed in terms of watts per square meter $\left(\mathrm{w} / \mathrm{m}^{2}\right)$, milliwatts per square centimeter $\left(\mathrm{mw} / \mathrm{cm}^{2}\right)$ or microwatts per square centimeter $\left(\mu \mathrm{w} / \mathrm{cm}^{2}\right)$.

For the case where the exposure is local (RF is transmitted from the mobile phone and hence closer to the user), the highest power absorption per unit mass in a small part of the body must be used and compared with the recommendations and standards. Specific Absorption Rate (SAR) is the quantity used to measure this amount of RF energy and it is expressed in units of watts per kilogram $(\mathrm{W} / \mathrm{kg})$ or $(\mathrm{mW} / \mathrm{kg})$. 
The Maximum Permissible Exposure (MPE) recommended for power density is based on the threshold SAR value. However some guidelines may vary from each other for different operating frequencies. Actually, Whole-body human absorption of RF energy varies with the frequency of the RF wave [11]. The frequency range of 30-300 MHZ is considered as the resonance range to human body where it absorbs the energy efficiently when the whole body is exposed [11].

The Maximum Permissible Exposure (MPE) limits adopted by FCC in 1996 for both occupational and general public exposure expressed in terms of electric field strength $(\mathrm{E}, \mathrm{v} / \mathrm{m})$ and magnetic field strength $(\mathrm{H}, \mathrm{a} / \mathrm{m})$ and power density $(\mathrm{S}, \mathrm{w} / \mathrm{m} 2)$ for a wide frequency range are given in Table 7. Similarly, the ICNIRP limits for frequencies up to $300 \mathrm{GHz}$ are given in Table 8. The details of the MPE for both ICNIRP and FCC are given in [14] and [15] respectively. In the far field of a transmitting antenna (plane wave case) the magnetic field may be given as E/377 and the power density is calculated as given in Eq.1.

$$
S=\frac{E^{2}}{377}
$$

Where $\mathrm{E}$ is the electric field strength $(\mathrm{v} / \mathrm{m})$

Table 7. FCC Limits for Maximum Permissible Exposure (MPE).

(A) Limits for Occupational/Controlled Exposure

\begin{tabular}{|c|c|c|c|c|}
\hline $\begin{array}{c}\text { Frequency } \\
\text { Range } \\
(\mathrm{MHz})\end{array}$ & $\begin{array}{c}\text { Electric field } \\
\text { Strength (E) } \\
\quad(V / m)\end{array}$ & $\begin{array}{c}\text { Magnetic field } \\
\text { Strength }(\mathbf{H}) \\
(\mathrm{A} / \mathrm{m})\end{array}$ & $\begin{array}{c}\text { Power } \\
\text { density } \\
(\mathbf{S}) \\
\left(\mathbf{m W} / \mathbf{c m}^{2}\right)\end{array}$ & $\begin{array}{c}\text { Averaging } \\
\text { Time } \\
|\mathbf{E}|^{2},|\mathbf{H}|^{2} \text { or } S \\
\text { (minutes) }\end{array}$ \\
\hline $0.3-3.0$ & 614 & 1.63 & $(100)^{*}$ & 6 \\
\hline $3.0-30$ & $1842 / \mathrm{f}$ & $4.89 / \mathrm{f}$ & $(900 / f 2)^{*}$ & 6 \\
\hline $30-300$ & 61.4 & 0.163 & 1.0 & 6 \\
\hline $300-1500$ & -- & -- & $\mathbf{f} / \mathbf{3 0 0}$ & 6 \\
\hline $1500-100,000$ & -- & -- & 5 & 6 \\
\hline
\end{tabular}

(B) Limits for General Population/Uncontrolled Exposure

\begin{tabular}{|c|c|c|c|c|}
\hline $\begin{array}{c}\text { Frequency } \\
\text { Range } \\
(\mathrm{MHz})\end{array}$ & $\begin{array}{c}\text { Electric field } \\
\text { Strength (E) } \\
\quad(\mathrm{V} / \mathrm{m})\end{array}$ & $\begin{array}{c}\text { Magnetic field } \\
\text { Strength (H) } \\
(\mathbf{A} / \mathbf{m})\end{array}$ & $\begin{array}{c}\begin{array}{c}\text { Power } \\
\text { density }\end{array} \\
(\mathbf{S}) \\
\left(\mathbf{m W} / \mathrm{cm}^{2}\right)\end{array}$ & $\begin{array}{c}\text { Averaging } \\
\text { Time } \\
|\mathbf{E}|^{2},|\mathbf{H}|^{2} \text { or } S \\
\text { (minutes) }\end{array}$ \\
\hline $0.3-1.34$ & 614 & 1.63 & $(100)^{*}$ & 30 \\
\hline $1.34-30$ & $824 / f$ & $2.19 / \mathrm{f}$ & $(180 / \mathrm{f} 2)^{*}$ & 30 \\
\hline $30-300$ & 27.5 & 0.073 & 0.2 & 30 \\
\hline $300-1500$ & -- & -- & f/1500 & 30 \\
\hline $1500-100,000$ & -- & -- & 1.0 & 30 \\
\hline
\end{tabular}

$$
\mathrm{f}=\text { frequency in } \mathrm{MHz}
$$$$
\text { equivalent power density }
$$

Table 8. ICNIRP reference levels for Maximum Permissible Exposure (MPE).

A) Limits for Occupational/Controlled Exposure*

\begin{tabular}{lcccc}
$\begin{array}{l}\text { Frequency } \\
\text { Range }\end{array}$ & $\begin{array}{c}\text { E-field } \\
\text { strength } \\
\left(\mathbf{V ~ m}^{-1}\right)\end{array}$ & $\begin{array}{c}\text { H-field } \\
\text { strength } \\
\left(\mathbf{A m ^ { - 1 } )}\right.\end{array}$ & $\begin{array}{c}\text { B-field } \\
(\boldsymbol{\mu} \mathbf{T})\end{array}$ & $\begin{array}{c}\text { Equivalent plane } \\
\text { wave power den- } \\
\text { sity } \mathbf{S}_{\text {eq }}\left(\mathbf{W m}^{-2}\right)\end{array}$ \\
\hline $\mathrm{Up} \mathrm{to} 1 \mathrm{~Hz}$ & - & $1.63 * 10^{5}$ & $2 * 10^{5}$ & - \\
$1-8 \mathrm{~Hz}$ & 20,000 & $1.63 * 10^{5} / \mathrm{f}^{2}$ & $2 * 10^{5} / \mathrm{f}^{2}$ & - \\
$8-25 \mathrm{~Hz}$ & 20,000 & $2 * 10^{4} / \mathrm{f}$ & $2.5^{*} 10^{4} / \mathrm{f}$ & - \\
$0.025-0.82 \mathrm{kHz}$ & $500 / \mathrm{f}$ & $20 / \mathrm{f}$ & $25 / \mathrm{f}$ & - \\
$0.82-65 \mathrm{KHz}$ & 610 & 24.4 & 30.7 & - \\
$0.065-1 \mathrm{MHz}$ & 610 & $1.6 / \mathrm{f}$ & $2.0 / \mathrm{f}$ & - \\
$1-10 \mathrm{MHz}$ & $610 / \mathrm{f}$ & $1.6 / \mathrm{f}$ & $2.0 / \mathrm{f}$ & - \\
$10-400 \mathrm{MHz}$ & 61 & 0.16 & 0.2 & 10 \\
$\mathbf{4 0 0 - 2 0 0 0 ~ M H z}$ & $3 \mathrm{f}^{1 / 2}$ & $0.008 \mathrm{f}^{1 / 2}$ & $0.01 \mathrm{f}^{1 / 2}$ & $\mathbf{f} / \mathbf{4 0}$ \\
$2-300 \mathrm{GHz}$ & 137 & 0.36 & 0.45 & 50 \\
\hline
\end{tabular}

*Note: $1 \mathrm{f}$ as indicated in the frequency range column.

(B) Limits for General Populations/Uncontrolled Exposure*

\begin{tabular}{lcccc}
\hline $\begin{array}{l}\text { Frequency } \\
\text { Range }\end{array}$ & $\begin{array}{c}\text { E-field } \\
\text { strength } \\
\left(\mathbf{V m}^{-1}\right)\end{array}$ & $\begin{array}{c}\text { H-field } \\
\text { strength } \\
\left(\mathbf{A m}^{-1}\right)\end{array}$ & $\begin{array}{c}\text { B-field } \\
(\boldsymbol{\mu} \mathbf{T})\end{array}$ & $\begin{array}{c}\text { Equivalent plane } \\
\text { wave power den- } \\
\text { sity } \mathbf{S}_{\text {eq }}\left(\mathbf{W m}^{-2}\right)\end{array}$ \\
\hline Up to $1 \mathrm{~Hz}$ & - & $3.2 \times 10^{4}$ & $4 \times 10^{4}$ & - \\
$1-8 \mathrm{~Hz}$ & 10.000 & $3.2 \times 10^{4} / \mathrm{f}$ & $4 \times 10^{4} / \mathrm{f}$ & - \\
$8-25 \mathrm{~Hz}$ & 10.000 & $4.000 / \mathrm{f}$ & $5,000 / \mathrm{f}$ & - \\
$0.025-0.8 \mathrm{kHz}$ & $250 / \mathrm{f}$ & $4 / \mathrm{f}$ & $5 / \mathrm{f}$ & - \\
$0.8-3 \mathrm{kHz}$ & $250 / \mathrm{f}$ & 5 & 6.25 & - \\
$3-150 \mathrm{kHz}$ & 87 & 5 & 6.25 & - \\
$0.15-1 \mathrm{MHz}$ & 87 & $0.73 / \mathrm{f}$ & $0.92 / \mathrm{f}$ & - \\
$1-10 \mathrm{MHz}$ & $87 / \mathrm{f}^{1 / 2}$ & $0.73 / \mathrm{f}$ & $0.92 / \mathrm{f}$ & - \\
$10-400 \mathrm{MHz}$ & 28 & 0.073 & 0.092 & 2 \\
$\mathbf{4 0 0 - 2 0 0 0 ~ M H z}$ & $1.375 \mathrm{f}^{1 / 2}$ & $0.0037 \mathrm{f}^{1 / 2}$ & $0.0046 \mathrm{f}^{1 / 2}$ & $\mathbf{f} / \mathbf{2 0 0}$ \\
$2-300 \mathrm{GHz}$ & 61 & 0.16 & 0.20 & 10 \\
\hline
\end{tabular}

*Note: $1 \mathrm{f}$ as indicated in the frequency range column.

It is clear from these recommendations that the MPE is a function of the operating frequency. Hence for $900 \mathrm{MHz}$ the MPE for both FCC and CNIRP is shown in the Table 9.

Table 9. MPE for both FCC and ICNIRP at 900MHZ.

\begin{tabular}{lcc}
\hline & FCC $\left(\mathbf{W} / \mathbf{m}^{2}\right)$ & $\operatorname{ICNIRP}\left(\mathbf{W} / \mathbf{~ m}^{2}\right)$ \\
\hline General public exposure & 6 & 4.5 \\
Occupational exposure & 30 & 22.5 \\
\hline
\end{tabular}

The Specific Absorption Rate (SAR) is a value that corresponds to the relative amount of RF energy absorbed by certain amount of the tissues of the body which is exposed to RF radiation. The FCC adopted limits for localized 'partial body' absorption in 
terms of SAR, which apply to certain portable transmitters such as hand-held mobile telephones. A similar principle is adopted by the ICNIRP for the frequencies up to $10 \mathrm{GHz}$ as shown in Table 10. These limits were set such that a safety factor of 10 and 50 were considered for the basic restrictions for occupational and general public exposures, respectively. The ICNIRP guidelines are generally accepted around the world. However, some countries such as USA and Canada have their own national SAR limits. A comparison between the SAR limits set by FCC and ICNIRP is shown in Table 11 for the $900 \mathrm{MHz}$ operating frequency.

Table 10. The SAR and basic restrictions set by ICNIRP*.

\begin{tabular}{|c|c|c|c|c|c|}
\hline $\begin{array}{l}\text { Exposure } \\
\text { character- } \\
\text { istics }\end{array}$ & $\begin{array}{c}\text { Frequency } \\
\text { range }\end{array}$ & $\begin{array}{l}\text { Current den- } \\
\text { sity for head } \\
\text { and trunk } \\
\left(\mathrm{mA} \mathrm{m}^{-2}\right) \\
(\mathrm{rms})\end{array}$ & $\begin{array}{l}\text { Whole- } \\
\text { body aver- } \\
\text { age SAR } \\
\left(\mathrm{Wkg}^{-1}\right)\end{array}$ & $\begin{array}{c}\text { Local- } \\
\text { ized SAR } \\
\text { (head and } \\
\text { trunk) (W } \\
\left.\quad \mathrm{kg}^{-1}\right)\end{array}$ & $\begin{array}{c}\text { Localized } \\
\text { SAR } \\
(\text { limbs) } \\
\left(\mathbf{W k g}^{-1}\right)\end{array}$ \\
\hline \multirow{6}{*}{$\begin{array}{l}\text { Occu- } \\
\text { pational } \\
\text { exposure }\end{array}$} & $\mathrm{Up}$ to $1 \mathrm{~Hz}$ & 40 & - & - & - \\
\hline & $1-4 \mathrm{~Hz}$ & $40 / f$ & - & - & - \\
\hline & $4 \mathrm{~Hz}-1 \mathrm{kHz}$ & 10 & - & - & - \\
\hline & $1-100 \mathrm{kHz}$ & $\mathrm{f} / 100$ & - & - & - \\
\hline & $\begin{array}{c}100 \mathrm{kHz}- \\
10 \mathrm{MHz}\end{array}$ & $f / 100$ & 0.4 & 10 & 20 \\
\hline & $\begin{array}{c}10 \mathrm{MHz}- \\
10 \mathrm{GHz}\end{array}$ & - & 0.4 & 10 & 20 \\
\hline \multirow{6}{*}{$\begin{array}{l}\text { General } \\
\text { public } \\
\text { exposure }\end{array}$} & $\mathrm{Up}$ to $1 \mathrm{~Hz}$ & 8 & - & - & - \\
\hline & $1-4 \mathrm{~Hz}$ & $8 / \mathrm{f}$ & - & - & - \\
\hline & $4 \mathrm{~Hz}-1 \mathrm{kHz}$ & 2 & - & - & - \\
\hline & $1-100 \mathrm{kHz}$ & $\mathrm{f} / 500$ & - & - & - \\
\hline & $\begin{array}{l}100 \mathrm{kHz}- \\
10 \mathrm{MHz}\end{array}$ & $\mathrm{f} / 500$ & 0.08 & 2 & 4 \\
\hline & $\begin{array}{l}10 \mathrm{MHz}- \\
10 \mathrm{GHz}\end{array}$ & - & 0.08 & 2 & 4 \\
\hline
\end{tabular}

*Note: $1 \mathrm{f}$ is the frequency in hertz. 2 average time is 6 minuets

Table 11. FCC and ICNIRP limits for Localized (Partial-body) Exposure*.

\begin{tabular}{clcc}
\cline { 3 - 4 } & & ICNIRP (W/kg) & FCC (W/kg) \\
\hline \multirow{2}{*}{ Occupational } & Whole-body & 0.4 & 0.4 \\
& Head and trunk & 10 & 8 \\
& Whole-body & 0.08 & 0.08 \\
General public & Head and trunk & 2 & 1.6 \\
\hline
\end{tabular}

* averaged over 1 gram of tissue

\section{Measurements}

Most of the governments put certain requirements on companies who want to operate and construct base station antennas, these re- quirements concerns the worst case estimate of the RF-EMF public exposure before the development can occur. Initially, some prediction values can be considered for the RF-EMF using some software tools, this can be achieved theoretically before the site is constructed. However, more accurate results can be obtained by measuring the radiated levels and compare it to the calculated ones. Measuring the exposure levels at a certain number of sites is necessary to verify the calculations and assess the actual exposure levels.

As this work focuses on the already constructed and operating base stations, then the radiation measurement is the practical issue to be performed. This has to be repeated occasionally and the values are to be compared with the international guidelines. Hence, sensitive equipment is required to measure the radio signals around the area of interest. A power density meter may be used to measure the electric field, magnetic field and power density in the vicinity of a mobile base station.

The device which was used here has an isotropic antenna and works in the frequency range of $0.2-3 \mathrm{GHz}$. This relatively wide range covers many common radio frequencies but not only the cellular communication band and so the measured power density values are not due to the mobile base station only. A portable electric field meter (E field) with detachable isotropic probe was used to take the necessary readings. The main specifications of the measuring device are illustrated in Table 12.

Table 12. Specifications of the field measuring device.

\begin{tabular}{lc}
\hline Wide dynamic range: & $0.2-600 \mathrm{~V} / \mathrm{m}$. \\
Resolution (at range): & $0.01 \mathrm{~V} / \mathrm{m}(2 \mathrm{~V} / \mathrm{m}$ and $20 \mathrm{~V} / \mathrm{m})$, \\
Broad frequency range: & $0.1 \mathrm{~V} / \mathrm{m}(200 \mathrm{~V} / \mathrm{m}), 1 \mathrm{~V} / \mathrm{m}(600 \mathrm{~V} / \mathrm{m})$. \\
Probe directivity: & $0.2 \mathrm{MHz}-3 \mathrm{GHz}$. \\
Ranges (V/m ,full scale): & Omni directional (Isotropic probe). \\
Calibration accuracy: & $2,20,200,600$. \\
& $+/-1.5 \mathrm{~dB}$ (at reference levels). \\
Probe frequency rotational : & Typically $+/-1 \mathrm{~dB}$. \\
Probe frequency isotropicity: & $+/-1 \mathrm{~dB}(2 \mathrm{MHz}-2 \mathrm{GHz})$, \\
Operating modes: & $+3 \mathrm{~dB} @ 0.2 \mathrm{MHz}:-2.5 \mathrm{~dB} @ 3 \mathrm{GHz}$. \\
Reading & Average, Pulse AND Peak. \\
\hline
\end{tabular}

A series of RF-EMF measurements in the form of electric field at the vicinity of several mobile telephone base stations in the city of Nablus were conducted in order to determine the exposures of the general public. The relationship between the RF power density levels specified in the safety guidelines and some typical RF power density levels actually measured around mobile phone base stations will be given.

Several typical $900 \mathrm{MHz}$ sites were considered, the first one had three antennas, A, B and C, and each of them has a gain of $9 \mathrm{dBi}$ and zero tilting angles with a height of the antennas as 17 $\mathrm{m}$. The electric field intensity was measured at different distances from the base station. Accordingly, the magnetic field and power density were calculated and recorded as shown in Table 13. The process has been repeated for five different sites with antenna gain of $6,9,12,15$ and $15 \mathrm{dBi}$ and with a tilting angle ranges from 0 to 4 . The measured values of the electric field and the correspond- 
Table 13. EMF field measurements for site-1.

\begin{tabular}{|c|c|c|c|c|c|c|c|c|c|}
\hline \multirow{2}{*}{$\begin{array}{c}\text { Cell ID } \\
\begin{array}{c}\text { Distance } \\
\text { (m) }\end{array}\end{array}$} & \multicolumn{3}{|l|}{ Cell A } & \multicolumn{3}{|l|}{ Cell B } & \multicolumn{3}{|l|}{ Cell C } \\
\hline & $\mathbf{V} / \mathbf{m}$ & $\mathbf{A} / \mathbf{m}$ & $\mathbf{W} / \mathbf{m}^{2}$ & $\mathbf{V} / \mathbf{m}$ & $\mathbf{A} / \mathbf{m}$ & $\mathbf{W} / \mathbf{m}^{2}$ & $\mathbf{V} / \mathbf{m}$ & $\mathbf{A} / \mathbf{m}$ & $\mathbf{W} / \mathbf{m}^{2}$ \\
\hline 3 & 1.85 & 0.0049 & 0.0091 & 1.74 & 0.0046 & 0.0080 & 2.11 & 0.0056 & 0.0118 \\
\hline 6 & 2.77 & 0.0073 & 0.0203 & 2.75 & 0.0072 & 0.0201 & 2.02 & 0.0053 & 0.0108 \\
\hline 10 & 3.49 & 0.0092 & 0.0323 & 1.43 & 0.0038 & 0.0054 & 2.61 & 0.0069 & 0.0181 \\
\hline 15 & 2.94 & 0.0078 & 0.0229 & 1.45 & 0.0038 & 0.0055 & 1.56 & 0.0041 & 0.0064 \\
\hline 20 & 0.70 & 0.0018 & 0.0013 & 1.74 & 0.0046 & 0.0080 & 2.7 & 0.0071 & 0.0193 \\
\hline
\end{tabular}

Table 14. EMF field measurements for five sites.

\begin{tabular}{|c|c|c|c|c|c|c|c|c|c|}
\hline Cell ID & Cell A & & & Cell B & & & Cell C & & \\
\hline $\begin{array}{c}\text { Distance } \\
\text { (m) }\end{array}$ & $\mathrm{V} / \mathrm{m}$ & $\mathbf{A} / \mathbf{m}$ & $\mathbf{W} / \mathbf{m}^{2}$ & $\mathrm{~V} / \mathrm{m}$ & $\mathbf{A} / \mathbf{m}$ & $\mathbf{W} / \mathbf{m}^{2}$ & $\mathrm{~V} / \mathrm{m}$ & $\mathbf{A} / \mathbf{m}$ & $\mathbf{W} / \mathbf{m}^{2}$ \\
\hline 3 & 1.80 & 0.0047 & 0.0086 & 2.25 & 0.0059 & 0.0134 & 3.06 & 0.0081 & 0.0248 \\
\hline 6 & 2.56 & 0.0068 & 0.0173 & 2.52 & 0.0066 & 0.0168 & 2.04 & 0.0054 & 0.0110 \\
\hline 10 & 3.33 & 0.0088 & 0.0294 & 1.02 & 0.0027 & 0.0027 & 2.04 & 0.0055 & .00117 \\
\hline 15 & 2.98 & 0.0079 & 0.0235 & 1.01 & 0.0026 & 0.0027 & 1.03 & 0.0027 & 0.0028 \\
\hline 20 & 1.81 & 0.0048 & 0.0086 & 1.02 & 0.0027 & 0.0027 & 1.08 & 0.0028 & 0.0031 \\
\hline
\end{tabular}

ing calculated values of the magnetic field and power density were averaged and recorded as shown in Table 14.

For a radiation source with omni direction and with no reflected signals the received signal strength decreases as the receiver moves far away from the source. In our case, the received signal depends on the reflected signal as well as the tilting angle of the antenna as shown in Fig 4. This explains the reason why the measured values are not consistence with the distance from the source. Moreover, it was clearly noticed that a reasonable amount of the received power was either removed or added to the received amount when the measurement is interrupted by a moving body like a car.

Considering a typical distance of 20 meter away from the first base station, the electric field was measured as $0.7 \mathrm{v} / \mathrm{m}$ leading to a power density of $0.0013 \mathrm{w} / \mathrm{m}^{2}$, which is $0.000288 \%$ of the ICNIRP limit and $0.002166 \%$ of the FCC limit. On the other hand, the maximum value of the electric field density was measured at a distance of 10 meters from the base station as $3.49 \mathrm{v} / \mathrm{m}$; this value leads to a power spectral density of $0.0323 \mathrm{w} / \mathrm{m}^{2}$ which is $0.00718 \%$ of the ICNIRP limit and $0.00538 \%$ of the FCC limit. These results show that the measured and calculated values for the electric field, the magnetic field and the power density around the city were small compared to the international standards.

This low radiation could be due to the restrictions put on the local mobile communication operator in using a limited number of frequencies and so the same frequency must be reused again in a short distance and hence the radiated power should be kept minimum so as to prevent interference [16].

Even though the power density emitted by the base stations is lower than the permitted levels but it is still very important to measure the power radiated by the mobile station itself, this power is believed to be more than the received one from the base station. Moreover, there are some other sources of EMF radiation in the area; this includes the local TV and FM transmitters and the WLAN. Hence, it is important to investigate the radiation from these sources.

\section{Conclusion}

Measuring the electromagnetic radiation from some cellular base stations around the city of Nablus has been performed at several sites. This is to answer the public concern wither they are safe being close to these stations and being exposed continuously to its radiation. The obtained readings were compared to some international standards and guidelines. It has been noticed that the maximum measured value was only $0.007 \%$ of the ICNIRP and $0.005 \%$ of the FCC international limits. Moreover, the measured values were not only due to the mobile base stations, but also due to all other sources of radiation in the range of $200 \mathrm{kHz}$ to $3 \mathrm{GHz}$. The signals here may have either destructive or instructive interference at some specific point, hence it is recommended that the radiation due to the base stations should be investigated together with the other sources like local TV, FM and WLAN transmitters, this may be achieved using a suitable spectrum analyzer. Another important issue is that the radiation exposure to the mobile station itself should be measured since it may have a much larger value being very close to the users. 


\section{References}

1. P. Mohana Shankar, "Introduction to Wireless Systems", Johan Wiley \& Sons, INC., 2002.

2. Jon W. Mark, Weihava Zhuang, "Wireless communication and networking", Prentice Hall, 2003.

3. Theodore S. Rappaport, "Wireless Communications, Principles \& practice", $2^{\text {nd }}$ edition, Prentice Hall, 2002.

4. William Stallings, "Wireless communication and networks", Prentice Hall, 2002.

5. MOLISH BOOK.

6. K. Fuller, et. al., "Radio Frequency Electromagnetic Fields in the Cookridge Area of Leeds", National Radiation Protection Board, NRPBw23, September, 2002, ISBN 0859514943.

7. International telecommunications Union, http://www.itu.int/net/home/index.aspx

8. http://www.ctia.org/

9. Physicians and Scientists for Responsible Application of science and Technology, "Mobile phones-safety Problems", September, 2004, www. psrast.org

10. G. J. Hyland, "Potential Adverse Health Impacts of Mobile Technology,
Memorandum", Department of physics, University of Warwick and International Institute of Biophysics, Feb. 2000.

11. Federal Communications Commission, http://www.fcc.gov/

12. John Muvlder, "Cellular Phone Antennas (Base Stations) and Human Health", Medical college of Wisconsin, http://www.mcw.edu/gcrc/cop/ cell-phone-health-FAQ/toc.htmloo, modified 3-April-2005.

13. World Health Organization, http://www.who.int/en/

14. International Commission for Non-Ionizing Radiation Protection (ICNIRP), "Guidelines for Limiting Exposure to Time-Varying Electric, Magnetic and Electromagnetic Fields (up to $300 \mathrm{GHz}$ )", Health Physics Society, Vol.74, No.4, PP.494-522, April 1998.

15. Federal Communication Commission, office of Engineering and Technology, "Questions \& Answers about Biological Effects \& Potential Hazards of radio frequency Electromagnetic Fields", OET56, 4" edition, August 1999.

16. Mousa A., Al Saleh R., "Problems and Suggested Solutions to Improve the Mobile Communications Network in Nablus", Information and Communication Technologies International Symposium (ICTIS05), pp. 415420, Tetuan - Morocco, 3-6 June 2005. 